\title{
ДИСТАНЦІЙНА СИСТЕМА НАВЧАННЯ ЯК ЗАСІБ ДЛЯ ЗДОБУТТЯ ОСВІТНЬОЇ КВАЛІФІКАЦІЇ БАКАЛАВРА ТА МАГІСТРА МЕДСЕСТРИНСТВА В ТЕРНОПІЛЬСЬКОМУ ДЕРЖАВНОМУ МЕДИЧНОМУ УНІВЕРСИТЕТІ ІМЕНІ \\ І. Я. ГОРБАЧЕВСЬКОГО
}

\author{
В. П. Марценюк, Н. І. Рега, В. Є. Городецький
}

Тернопільський державний медичний університет імені І. Я. Горбачевського

У статті висвітлено досвід дистанційної освіти для здобуття кваліфікації бакалавра та магістра медсестринства в Тернопільському державному медичному університеті імені І. Я. Горбачевського.

Ключові слова: дистанційне навчання, медична освіта

\section{ДИСТАНЦИОННАЯ СИСТЕМА ОБУЧЕНИЯ КАК СРЕДСТВО ДЛЯ ПОЛУЧЕНИЯ КВАЛИФИКАЦИИ БАКАЛАВРА И МАГИСТРА МЕДСЕСТРИНСТВА В ТЕРНОПОЛЬСЬКОМ ГОСУДАРСТВЕННОМ МЕДИЦИНСКОМ УНИВЕРСИТЕТЕ ИМЕНИ И.Я. ГОРБАЧЕВСКОГО}

\author{
В. П. Марценюк, Н. И. Рега, В. Е. Городецкий \\ Тернопольский государственный медицинский университет \\ имени И. Я. Горбачевского
}

\begin{abstract}
В статье освещен опыт внедрения дистанционной системы обучения для достижения квалификации бакалавра и магистра медсестринства в Тернопольськом государственном медицинском университете имени И. Я. Горбачевского.
\end{abstract}

Ключевые слова: дистанционное обучение, медицинское образование.

\section{DISTANT LEARNING SYSTEM FOR QUALIFYING BACHELOR AND MASTER OF NURSING IN TERNOPIL STATE MEDICAL UNIVERSITY} BY I. Ya. HORBACHEVSKY

\author{
V. P. Martsenyuk, N. I. Reha, V. Ye. Horodetskyi \\ Ternopil State Medical University by I. Ya. Horbachevsky
}

\begin{abstract}
The article deals with the questions implementation of distant education for gualifying Bachelor and Master of Nursing at Ternopil State Medical University by I. Ya. Horbachevsky.
\end{abstract}

Key words: distant learning, medical education.

Вступ. Одним із елементів реформування системи медичної освіти в Україні є ступенева підготовка медичних сестер - молодших медичних спеціалістів, бакалаврів та магістрів. Професійним завданням останніх є участь у навчанні та післядипломній перепідготовці основної маси медичних сестер, а також керівництво ними у практичній роботі у якості організаторів та менеджерів охорони здоров'я [1]. Велику увагу необхідно приділяти освіті медсестер на рівні світових стандартів. Сестринська справа поєднує у

О В. П. Марценюк Н. І. Рега, В. Є. Городецький собі одночасно мистецтво і науку. Вона вимагає оволодіння специфічними навиками, знаннями і умінням їх практичного застосування. Розширення самостійності медичних сестер при організації догляду за хворими та збільшення кількості і об' єму маніпуляцій при догляді за пацієнтом можна домогтися за певних умов, якими є отримання якісної професійної освіти та відповідно адекватної їй заробітної плати, створення сучасного матеріально-технічного забезпечення робочих місць, наукова організація праці 3 
урахуванням нових технологій у лікувально-діагностичному процесі тощо [2].

Основна частина. Виникнення глобальної мережі Інтернет стало поштовхом до створення та розвитку навчання за допомогою нових інформаційних технологій, а також загального поширення дистанційної форми навчання. Всесвітня павутина спричинила розвиток мережевих технологій, а також надала можливість студентам та викладачам використовувати електронні підручники, бібліотеки, зручні системи тестування та інформаційні засоби спілкування. Інтернет дозволив не тільки об'єднати всі раніше відомі інструменти навчання, але і помітно розширити їх перелік, зробивши істотний вплив на інформаційну культуру в освітньому середовищі. Сьогодні навчання засобами Інтернету все частіше розглядається як альтернатива традиційній освіті, яка дозволяє студентові отримати глибокі знання. Одним з видів навчання за допомогою мережі Інтернет є дистанційна форма навчання [3].

Дистанційне навчання - це форма отримання освіти, при якій в освітньому процесі використовуються кращі інноваційні засоби та форми навчання, що грунтуються на комп' ютерних і телекомунікаційних технологіях [4]. У дистанційному навчанні перевага віддається самостійній роботі студента. Суб'єкт і об'єкт навчання мають можливість здійснювати навчальну діяльність у зручному для себе місці, за попередньо узгодженою схемою й індивідуальним інтервальним графіком взаємодії в часі.

При дистанційному навчанні існують певні особливості, пов'язані, насамперед, з наявністю технологічних можливостей студента. Для навчання йому необхідно мати регулярний доступ до персонального комп'ютера, бажано з підключенням до Інтернету, на якому встановлена операційна система не нижче Windows 98. Навчатися можна в режимі on-line. При цьому використовуються спеціальні технології, серед яких поширені кейс-технології (базуються на пакетах навчально-методичних матеріалів для самостійного вивчення, контрольних завданнях і тестах контролю); телевізійні технології (базуються на замкнутих телевізійних системах із зворотним зв' язком); технології відеоконференцій (базуються на засобах забезпечення двостороннього або багатостороннього аудіо - відеозв'язку на значних відстанях); комбіновані технології [5].

Організація навчання передбачає вірно розплановані етапи засвоєння навчальної дисципліни: лекційні, практичні і лабораторні заняття, семінари, чати, форуми, виконання контрольних робіт, консультації з на- вчальних дисциплін, самостійна робота тощо. Основною формою отримання знань $є$ самостійна робота. У процесі навчання важлива роль надається методиці оцінювання отриманих знань та контролю за етапами навчання. Заключна стадія навчання передбачає повторювання й узагальнення. Вивчивши європейський та американський досвід проведення дистанційної форми навчання та заручившись підтримкою МОЗ України на базі Тернопільського державного медичного університету імені I. Я. Горбачевського відкрито центр дистанційного навчання для медсестер-бакалаврів та медсестер-магістрів [6]. Тривалість навчання становить 2 роки (4 семестри).

На базі центру підготовлена платформа дистанційного навчання, інтегрована з Web-порталом університету. Для відповідного напрямку підготовки фахівців 3 використанням технологій дистанційного навчання розроблений та затверджений навчальний план. Реєстрація абітурієнтів, які бажають навчатися за дистанційною формою, прийом документів, вступних іспитів та співбесіди здійснюються через Web-nopтал університету. На порталі трьома мовами (українською, російською, англійською) представлені для користувачів 3 авторизованим доступом методичні матеріали - розклади занять та лекцій, робочі програми з дисциплін, методичні вказівки, презентації лекцій, матеріали для підготовки до лекцій і практичних занять, інструкції щодо виконання практичних навичок, електронні підручники, навчальні таблиці [7].

Зв'язок викладача із студентом відбувається через мережу Інтернет на порталі університету двома основними способами: перший спосіб - обмін інформацією через поштові скриньки, розміщені на Webпорталі університету; другий спосіб - зв'язок через Інтернет у системі "Skype." Кожному студенту відкрита персональна електронна поштова скринька на Web-порталі університету та надано персональний пароль та логін доступу до нього на час проходження навчання. Через цю скриньку викладач підтримує зв'язок із студентом, а також студент має змогу відправляти власну інформацію на сриньку викладача. Викладач і студент також реєструються у системі "''Skype та через встановлені Web-камери проводять спілкування та вільно обмінюються інформацією з навчального процесу. Цей спосіб дає можливість ідентифікації особи (студента) і збільшує швидкість обміну інформацією. Напередодні (за день до початку викладання дисципліни) викладач зв'язується зі студентом шляхом відправлення необхідної інформації про методику навчального процесу 3 даної дисципліни. 
Контроль якості підготовки студентів здійснюють в межах кожної дисципліни, проводять вхідний, щоденний і поточний контроль знань під час контрольних та семінарських занять. Підсумковий контроль знань включає семестрові, семестрово-модульні диференційовані заліки та іспити, а також перевідні і державні іспити. На всіх етапах контролю якості підготовки студентів використовуються тестові завдання. Для дисциплін, формою контролю засвоєння яких визначено іспит, передбачено контроль у формі єдиного комплексного тестового іспиту на порталі університету.

Усі оцінки, отримані студентом протягом навчального процесу, заносяться у електронну базу університету „Контингент', а також у навчальні журнали по кафедрах згідно пройденої дисципліни.

За час існування системи дистанційної освіти в Тернопільському державному медичному університеті імені І. Я. Горбачевського кваліфікацію медичної сестри-бакалавра здобуло 158 чоловік, з них - 41 вітчизняний, 117 - іноземних громадян. В цьому році до випуску готуються 85 медичних сестер-бакалаврів, з них 17 вітчизняних, 68 - іноземних громадян. На першому курсі успішно навчаються ще 197 студентів, з них 52 - вітчизняних, 145 - іноземних. Цього року ступінь магістра медсестринства планують здобути 19 медичних сестер-бакалаврів, 3 них 15 вітчизняних та 4 іноземних. На першому курсі магістратури успішно навчаються ще 39 студентів, 3 них 30 - вітчизняних, 9 - іноземних. Окрім опановування навчальних дисциплін згідно з навчальним планом, студенти-магістранти успішно працюють над написанням індивідуальної наукової магістерської роботи під керівництвом наукових керівників. На першому курсі розпочали навчання 26 вітчизняних та 8 іноземних студентів. Зростання кількості студентів свідчить, що здобуття кваліфікацій медичної сестри - магістра медсестринства є необхідним на сучасному етапі, та прогнозує зростання попиту на освітні послуги 3 даного освітнього рівня саме на дистанційній формі навчання. Але уже зараз виник ряд проблемних питань, таких як забезпечення сучасною навчальною літературою у відповідності до затверджених освітніх стандартів підготовки магістрів з медсестринства, виділення баз проходження всіх видів практики з призначенням достатньо підготовлених керівників з практики та відповідним навчальним матеріально-технічним рівнем її забезпечення, виділення і надання відповідного статусу центрам післядипломної освіти. Вирішення цих пи- тань потребує значних організаційних зусиль, фінансових затрат та часу, а також необхідності створення нової нормативно-правової основи для їх запровадження. Адже без цього реформування системи медсестринської освіти може надовго загальмуватися та, відповідно, відтермінується наближення наших фахівців до міжнародних стандартів забезпечення якості їх навчання тарівня практичних умінь. Мережа університетських лікарень та клінік дозволить створити відповідне кадрове, навчально-методичне та матеріально-технічне забезпечення системної і послідовної клінічної підготовки майбутньої медичної сестри. Але питання її створення, оснащення сучасною апаратурою та забезпечення висококваліфікованими кадрами теж потребує затрат часу, фінансів та значних організаційних зусиль з одночасним вирішенням проблем на законодавчому рівні.

Необхідно також вирішувати питання щодо удосконалення та навчання медсестер-бакалаврів та магістрів протягом усього професійного життя. Розуміння складності змін, які безперервно відбуваються у сестринській справі, а також сприйняття сестринської справи як самостійної унікальної професії, сприяє тому, що багато медсестер вже усвідомлюють необхідність безперервної освіти впродовж всього життя, сенс якого полягає в тому, що людина може і повинна бути відкритою для нових ідей, рішень, навичок або моделей поведінки у будь-якому віці. Концепція "навчання впродовж всього життя" властива багатьом професіям, проте для медсестер вона $є$ особливо актуальною.

Висновки. Розвиток дистанційної освіти в Україні на сьогоднішній день відповідає вимогам до інформаційного суспільства, що прагне інтегруватись у європейську і світову спільноту.

Очікувані позитивні наслідки створення системи дистанційної освіти для магістрів медсестринства в Україні:

- розширення кола споживачів освітніх послуг, у тому числі у важкодоступних, малонаселенна регіонах, у районах, віддалених від наукових і культурних центрів України;

- підвищення якості навчання слухачів та студентів незалежно від їхнього місцезнаходження;

- створення додаткових робочих місць для громадян України;

- можливість одержання освіти за українськими програмами громадянам зарубіжних країн;

- реалізація системи безперервної освіти "через все життя"; 


\section{Література}

1. Про затвердження Положення про дистанційне навчання : Наказ МОН України від 21.01.2004 р. № 40 // Офіційний вісник України. - 2004. - №15. - С. 241-253.

2. Денисов Д. О. Дистанційна освіта в Україні // Актуальні питання дистанційної освіти, порівняння сучасного стану дистанційної освіти в Україні та країнах Західної Європи:

3б. наук, праць: У 2 ч. - Суми, 2004. - Ч. 1: Педагогіка та методика навчання і виховання. - С. 44-48.

3. Банчук М. В. Міністерство охорони здоров'я України, Сучасні завдання вищої медичної школи / М. В. Банчук, О. П. Волосовець, Т. І. Чернишенко //Магістр медсестринства. - № 1.-2008.-С.17-21.

4. Дистанційна освіта як новітній підхід до сгупеневої підготовки медичних сестер / Л. Я. Ковальчук, О. І. Яшан.
С. О. Ястремська, С. О. Коноваленко //Медсестринство. 2010 . - № 1, - С. 5-6.

5. Коноваленко С. О. Необхідність, проблеми та наслідки створення системи дистанційної освіти в Україні / С. О. Коноваленко, В. В. Максимова //Медсестринство. 2010 . -№2 .- C. 8-11.

6. Максимова В. В. Щодо проблемних питань з розвитку медсестринства в Україні / В. В. Максимова, С. О. Ястремська // Медсестринство. -2009. - № 3. - С. 15-19.

7. Дистанційна форма навчання в медсестринстві - перший результат впровадження / С. О. Ястремська,

О. С. Усинська, І. Я. Господарський, Н. І. Рега // Медсестринство. - 2011. - № 3. - С. 8-9. 